\title{
SURJÁN Orsolya
}

Nemzeti Népegészségügyi Központ, Budapest

E-mail: surjan.orsolya@nnk.gov.hu

DOI: https://doi.org/10.29179/EgTud.2021.3.26

\section{Helybe visszük a szürövizsgálatokat}

\section{Összefoglalás:}

Magyarország egyes területei közötti gazdasági egyenlőtlenség csökkentése érdekében a Nemzeti Népegészségügyi Központ a „Helybe visszük a szürővizsgálatokat” programmal csatlakozott.

A „Helybe visszük a szűrővizsgálatokat” program során használt szűrőbuszok működtetésének célja a prevenció és az egészségtudatosság erősítése, térítésmentes vizsgálatok biztosításával, az esélyegyenlőség megteremtésével.

A program, illetve a vizsgálatok körének összeállításakor elsősorban a magyar lakosság megbetegedési és halálozási mutatóit vettük figyelembe, mint ahogyan az mindenki előtt ismeretes a szív- és érrendszeri, valamint a daganatos megbetegedések a leggyakrabban előforduló kórképek.

A program során az együtt futó három vizsgálóbuszban minden településen egységesen biztosítjuk az általános állapotfelmérésen, nőgyógyászati és szájüregi szúrésen való részvételt, kardiológiai és stroke rizikószűrés után pedig nyaki ér ultrahang vizsgálatot, neurológiai, illetve kardiológiai szakvizsgálatot. Ezen túlmenően az arra jogosultaknak a vastagbélszürésiegységcsomag átvételét.

Az általános állapotfelmérés magába foglalja a vércukor és koleszterint meghatározást, vérnyomás és artériás oxigén telítettség mérést, BMI kalkulációt, haskörfogat mérést, testösszetétel analízist (InBody készülékkel), csontsúrúség mérést, légzésfunkciós vizsgálatot, EKG-t és boka-kar index vizsgálatot, ami a perifériás érbetegség, közismert nevén az érszúkületről ad képet, valamint az életmódra és családi anamnézisre is kitérő kardiológiai és stroke rizikóbecslés kérdőív kitöltését.

Az ellátást a Nemzeti Népegészségügyi Központ (NNK), a Gottsegen György Országos Kardiovasculáris Intézet és az NNK-val szerződéses jogviszonyban álló helyi/megyei egészségügyi szolgáltatók szakemberei biztosítják.

A 2019 évben útjára indított program immár harmadik éve múködik, tervezetten minden év áprilisa és októbere között történik.

A szűrővizsgálatok és állapotfelmérések egyre szélesebb körét nyújtva a lakosság legnagyobb megelégedésére.

Kulcsszavak: állapotfelmérés, népegészségügy, szürövizsgálat 